\title{
Peningkatan Keaktifan Belajar Subtema Kerjasama Ekonomi Internasional melalui Pendekatan Ekspositori pada Siswa Kelas IX
}

\author{
Ta'awan $^{(1)}$ \\ ${ }^{1}$ SMP Negeri 1 Blitar, \\ Email: 1d_shin13@yahoo.com
}

\begin{abstract}
ABSTRAK
Siswa di SMP Negeri 1 Blitar khususnya kelas IX kurang berminat belajar IPS.. Sehingga perlu dilakukan suatu Penelitian Tindakan Kelas yang bertujuan untuk meningkatkan minat dalam pembelajaran IPS. Penelitian Tindakan Kelas ini dilakukan dalam tiga siklus terdiri dari tahaptahap : Perencanaan, Tindakan, Pengumpulan Data, dan Refleksi. Tindakan berupa Penerapan Pendekatan Ketrampilan Proses. Yang tekniknya disesuaikan dengan tema atau topik yang sedang berlangsung. Respon kemajuan minat belajar IPS diperoleh dari angket siswa, wawancara dengan siswa, observasi kegiatan pembelajaran, wawancara antar guru, jurnal guru, hasil Ulangan Harian dan tugas. Validasi instrumen dilakukan dengan critical reflection antar guru peneliti dan face validity. Validasi data dilakukan dengan triangulasi observasi dari aspek siswa, guru dan guru mitra. Hasil refleksi tiap siklus digunakan untuk merencanakan langkah-langkah lanjutan. Hasil tindakan kelas menunjukkan kelas yang diajar dengan pendekatan Ekpositori dalam pembelajaran IPS mengalami kenaikan prestasi belajar dalam bentuk rata-rata ulangan Harian pada tiap-tiap siklus. Dari hasil analisa data ternyata siswa yang diajar dengan pendekatan Ekspositori lebih efektif dalam peningkatan motivasi dan prestasi belajar jika dibandingkan dengan siswa yang tidak diajar dengan pendekatan Ekspositori. Hal ini ditunjukkan dengan adanya peningkatan prosentase pemahaman siswa terhadap materi pembelajaran dari $41 \%$ menjadi $57,7 \%$, sementara siswa yang sering bertanya meningkat dari $4,3 \%$ di awal siklus menjadi $14,4 \%$ pada siklus ketiga.
\end{abstract}

Kata kunci: ekpositori, keaktifan, belajar,

\section{PENDAHULUAN}

Strategi pembelajaran Ekspositori adalah strategi pembelajaran yang menekankan kepada proses pencapaian materi secara verbal dari seorang guru kepada sekelompok siswa dengan maksud agar siswa dapat menguasai materi pelajaran secara optimal. Strategi pembelajaran Ekspositori disebut juga dengan strategi pembelajaran langsung, karena strategi ini materi disampaikan langsung oleh guru, siswa tidak dituntut untuk menemukan materi itu. Oleh karena itu strategi pembelajaran Ekspositori lebih menekankan kepada proses pembelajaran.

Berdasarkan pengalaman guru-guru kelas IX yang tergabung dalam tim Penelitian Tindakan Kelas SMP Negeri 1 Blitar hanya sedikit siswa yang menguasai materi pembelajaran IPS. Mereka yang menguasai hanya terbatas pada siswa yang pandai. Berdasarkan kenyataan materi pembelajaran IPS sebenarnya banyak berkaitan dengan realita kehidupan siswa di masyarakat, namun demikian banyak siswa yang kurang memanfaatkan konsep-konsep IPS dengan jalan bertanya pada guru. Sehingga pemahamannya pada materi pembelajaran dapat meningkat. Untuk mengatasi kendala seperti paparan di atas maka dipandang perlu untuk melakukan Penelitian Tindakan Kelas, khususnya tentang penelitian yang berkaitan dengan strategi pembelajaran Ekspositori.

Identifikasi masalah dalam penelitian ini, didasarkan pada hasil pengamatan guru pada kelas IXSMP Negeri 1 . Blitar. Terdapat beberapa faktor penyebab rendahnya Kemampuan siswa dalam menerapkan konsep Kerjasama Ekonomi Internasional disebabkan oleh 1) Guru tidak sempat mereview pengetahuan awal siswa yang merupakan prasyarat untuk memahami sub tema yang akan diajarkan, 2) 
Perhatian guru dalam kelas tidak merata, hanya terbatas kepada beberapa siswa, sehingga terkesan agak pilih kasih dan menjadi kurang simpatik, 3) Latihan dan tugas yang diberikan guru belum terencana dengan baik serta kurang bervariasi, 4) Siswa sulit berkonsentrasi dalam belajar, 5) Siswa belum dapat menyelesaikan tugas-tugas secara optimal, 6) Sebagian siswa minat belajarnya pada mata pelajaran IPS sangat rendah.

Strategi pembelajaran Ekspositori merupakan bentuk pendekatan pembelajaan yang berorientasi kepada guru. Melalui strategi ini guru menyampaikan materi pembelajaran secara terstruktur dengan harapan materi pelajaran yang disampaikan dapat dikuasai siswa dengan baik. Fokus utama strategi ini adalah kemampuan akademik siswa.

Strategi pembelajaran Ekspositori akan lebih efektif apabila: 1) Guru akan menyampaikan bahan-bahan baru serta kaitannya dengan yang akan dan harus dipelajari siswa, oleh sebab itu materi yang disampaikan adalah materi-materi dasar dan materi-materi esensial saja, artinya pengembangan lebih lanjut dapat dikembangkan oleh siswa sendiri atas bimbingan guru; 2) Apabila guru menginginkan agar siswa mempunyai gaya model intelektual tertentu; 3) Jika bahan pelajaran yang akan diajarkan cocok untuk dipresentasikan; 4) Jika ingin membangkitkan keingintahuan siswa tentang topik tertentu.

\section{METODE}

Penelitian direncanakan dengan mengimplementasikan penelitian tindakan kelas yang meliputi komponen-komponen : 1)Perencanaan / Planning, 2) Tindakan / Acting, 3) Observasi / Observing, 4) Refleksi / Reflekting. Penelitian berlangsung selama 3 bulan dari buan Januari 2016sampai dengan bulan Maret 2016 yang terbagi dalam 3 Siklus, masing-masing siklus dengan alokasi waktu 3 minggu ( 3 X 80 menit), setiap akhir siklus diakhiri dengan refleksi dan replanning untuk melanjutkan pada siklus 2 dan 3.

\section{Setting dan Karakteristik Penelitian}

Penelitian tindakan kelas dilaksanakan di SMP Negeri 1 Blitar dengan guru mitra kolaborator yaitu guru-guru rumpun IPS SMP Negeri 1 Blitar.Subyek penelitiannya adalah siswa dari SMP Negeri 1 Blitar yang berjumlah 37 siswa, terdiri dari 16 orang laki-laki dan 21 orang perempuan. Berdasarkan observasi yang dilakukan guru peserta Penelitian Tindakan Kelas terhadap proses belajar teridentifikasi bahwa akar permasalahan terlihat

Sebagai alternatif pemecahan masalah disusun perencanaan pelaksanaan tindakan kelas seperti diagram berikut ini

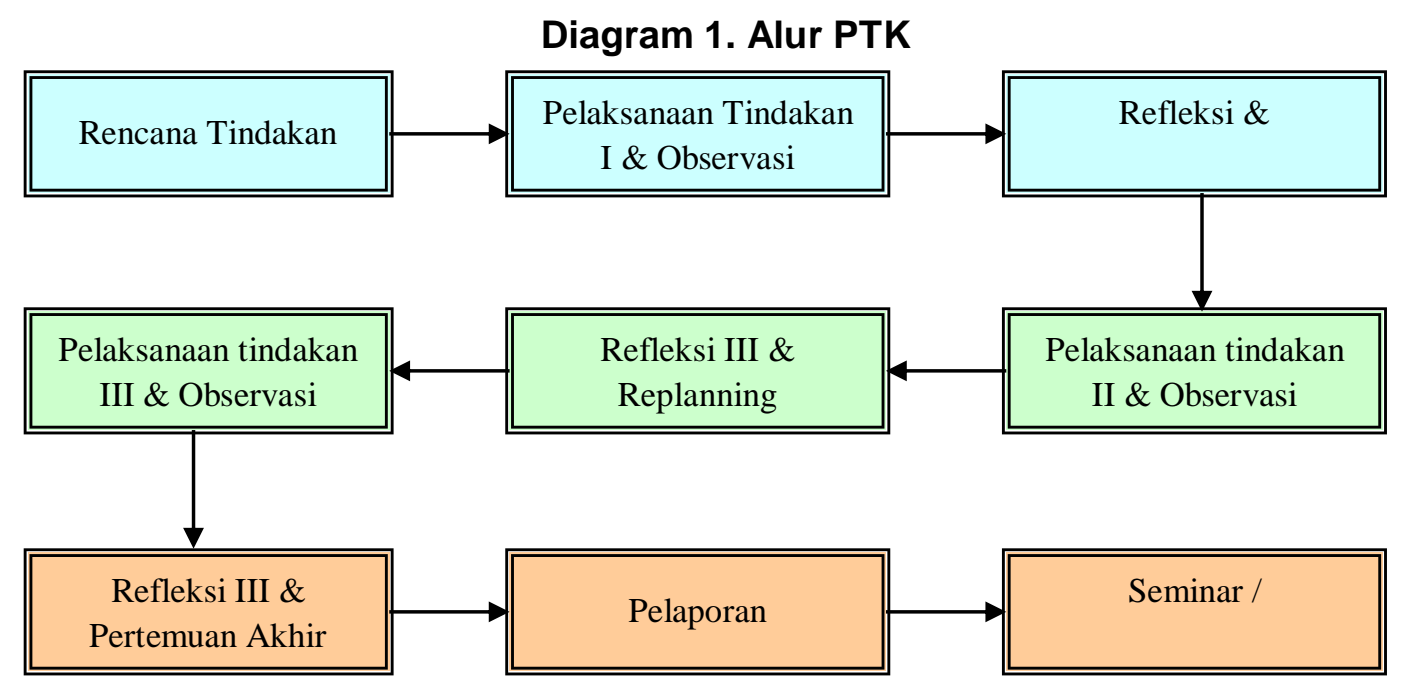




\section{Prosedur Penelitian}

Perlakuan dalam Penelitian Tindakan Kelas ini berlangsung secara siklus, yang terdiri dari 3 siklus. Pada siklus pertama seluruh hipotesis tindakan dilakukan secara terbagi. Pada akhir siklus pertama dilakukan analisis baik yang berupa keberhasilan maupun kegagalan sebagai bahan pertimbangan untuk memperbaiki perlakuan yang akan diberikan pada siklus kedua. Demikianlah seterusnya, siklus ketiga direncanakan berdasarkan analisis dan refleksi pada siklus sebelumnya. Dari hasil penelitian ini diambil dengan menggunakan: 1) Angket, 2) Observasi, 3) Wawancara terhadap siswa. Guru sebagai subyek penelitian terlibat langsung dalam kegiatan planning, acting, observing dan reflecting, tindakan-tindakan yang diberikan. Siswa melaksanakan kegiatan-kegiatan pembelajaran yang direncanakan guru secara aktif. Guru mitra atau kolaborator bertugas melakukan observasi baik terhadap guru maupun siswa. Dari data guru yang berkenaan dengan tindakan-tindakan yang diberikan, sedangkan dari murid berkenaan dengan perubahan-perubahan perilaku yang terjadi akibat tindakan tersebut. Konsultan memberikan bimbingan sejak pra penelitian berlangsung dan penyusunan laporan bulanan dan laporan akhir penelitian.

\section{Instrumen Penelitian}

Instrumen penelitian yang digunakan adalah 1) Lembar Observasiyang digunakan adalah observasi terstruktur dan teknik supervisi klinis ,2) Dokumen siswa berupa catatan siswa saat proses pembelajaran, 3) Catatan Lapangan yang diperlukan untuk merekam kejadian-kejadian selama proses pembelajaran berlangsung, 4) Kerangka Analisis Data.

\section{Pengelompokan Data}

Data yang diperoleh guru kemudian dikelompokkan untuk memudahkan analisisnya. Kelompok-kelompok tersebut adalah aktivitas, wawancara, dokumen siswa dan catatan lapangan. Data yang sudah dikelompokkan digunakan sebagai pertimbangan dalam menjawab Mengapa minat siswa belajar IPS rendah dan Bagaimana meningkatkan minat tersebut.

\section{Validitas Data}

Untuk memperoleh data yang valid, dan obyektif dalam penelitian digunakan teknik trianggulasi yaitu sebagai berikut : a) Menggali data dari sumber yang sama dengan menggunakan cara yang berbeda. b) Menggali data dari sumber yang berbeda untuk memperoleh informasi tentang hal yang sama, teknik ini dilakukan untuk memperoleh informasi tentang pemahaman siswa dengan memeriksa hasil tes siswa. c) Memeriksa kembali data-data yang telah terkumpul. d) Mengulang pengolahan dan analisis data yang sudah terkumpul. e) Memperhatikan pendapat ahli khususnya instruktur dan guru inti.

\section{Tindakan}

Hasil interpretasi data digunakan sebagai landasan dalam menyusun rencana tindakan yang lebih baik untuk diimplementsikan dalam pembelajaran selanjutnya.

\section{HASIL \\ Siklus I}

Pada siklus pertama ini sebagian besar para peserta tindakan kelas telah menyelesaikan materi pembelajaran materi Arti dan Tujuan Kerjasama Ekonomi Internasional. Pertemuan di kelas umumnya hanya membahas penyampaian materi. Pada siklus pertama guru memotivasi siswa dengan cara memberi penjelasan tentang pentingnya penguasaan materi dalam pembelajaran maupun dalam kehidupan sehari- 
hari. Guru menciptakan situasi kelas yang memungkinkan siswa bertanya, mengeluarkan pendapat dan menghargai pendapat siswa lainnya.

Selain itu guru melakukan pendekatan secara individual kepada siswa di kelas. Untuk mendukung proses pembelajaran pada siklus pertama ditampilkan gambar atau poster tentang arti Kerjasama Ekonomi Internasional dan Tujuan Kerjasama Ekonomi Internasional Pada siklus pertama ini didapat hasil Ulangan Harian siswa dengan nilai rata-rata kelas 69,2.

\section{Siklus II}

Pada siklus kedua guru membuat Rencana Pengajaran yang dilengkapi dengan masalah pengembangan atau penerapan sehingga dapat memotivasi siswa. Guru memberi tugas kepada siswa agar materi yang belum jelas ditanyakan terlebih dahulu dengan cara menuliskan pertanyaan di sehelai kertas. Guru lebih banyak mengembangkan teknik bertanya. Terhadap siswa yang diperkirakan belum memahami materi namun tidak mau bertanya dilakukan pendekatan secara individual.

Kegiatan pada siklus kedua ini diawali dengan penyampaian materi tentang Bentuk Bentuk Kerjasama Ekonomi Internasional.. Untuk mendukung proses pembelajaran pada siklus kedua ditampilkan gambar atau poster tentang Bentuk Bentuk Kerjasama Ekonomi Internasional. Pada siklus kedua ini didapat hasil Ulangan Harian siswa dengan nilai rata-rata kelas 74,9.

\section{Siklus III}

Tindakan pada siklus 3, guru membuat Rencana Pelajaran yang dilengkapi dengan alat bantu pengajaran. Guru memberi motivasi agar siswa berani bertanya dengan cara memberi tambah pada nilai tugas sebesar 0,5 untuk setiap pertanyaan yang diajukan. Hal ini dilakukan agar siswa termotivasi untuk mengajukan pertanyaan, khususnya bagi siswa yang enggan mengajukan pertanyaan. Guru melakukan pendekatan di dalam maupun diluar kelas. Untuk mendukung proses pembelajaran pada siklus ketiga ditampilkan gambar atau poster tentang Dampak Kerjasama Ekonomi Regional dan Internasional .

Pada siklus kedua ini didapat hasil Ulangan Harian siswa dengan nilai rata-rata kelas 79,8. Pada akhir siklus ketiga juga diadakan Ulangan Harian. Hasil dari Ulangan tersebut ternyata cukup memuaskan, jika sebelum siklus rata-rata Ulangan Harian adalah 65,6 maka, pada siklus pertama menjadi 69,2 sedangkan rata-rata Ulangan Harian pada siklus kedua menjadi 74,9 dan rata-rata Ulangan Harian pada akhir siklus ketiga menjadi 79,8 . Lengkapnya tercantum pada grafik dibawah ini.

\section{Grafik 1. Rata-rata Nilai Ulangan Harian Pra Siklus, Siklus 1, 2 dan 3}

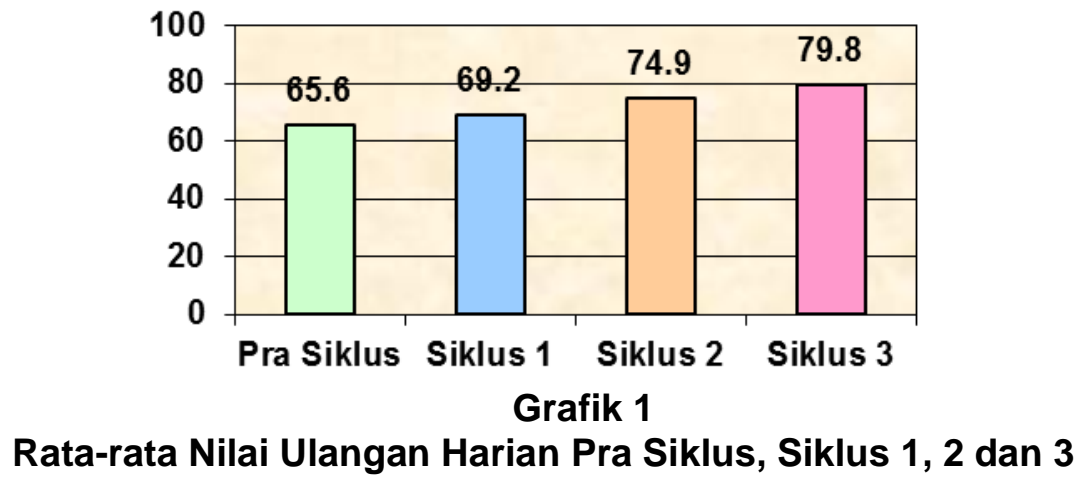

Selain itu, setiap siswa juga diminta untuk mengisi angket seperti yang telah mereka isi di awal penelitian. Hasil angket sebelum dan sesudah tindakan dapat dilihat pada tabel 1. Dari tabel tersebut dapat ditafsirkan hal-hal sebagai berikut: 1) Siswa yang belum merasa paham saat mempelajari materi mengalami kenaikan dari $41 \%$ menjadi $57,7 \%$. Kebenaran data ini diperkuat dengan hasil wawancara antara 
pengamat dengan siswa. 2) Banyaknya siswa yang sering bertanya juga meningkat dari $4,3 \%$ diawal siklus menjadi $14,4 \%$ di akhir siklus ketiga. Banyaknya siswa yang langsung bertanya bila menjumpai kesulitan meningkat dari 16,2\% menjadi $36,3 \%$ pada siklus ketiga.

\section{Tabel 1 \\ Hasil Angket}

\begin{tabular}{|c|c|c|c|}
\hline \multirow{2}{*}{ No } & \multirow{2}{*}{ Pertanyaan Dalam Angket } & \multicolumn{2}{|c|}{$\begin{array}{l}\text { Prosentase siswa } \\
\text { yang menjawab }\end{array}$} \\
\hline & & Awal & Akhir \\
\hline 1 & $\begin{array}{l}\text { Apakah kamu paham materi yang baru diajarkan? } \\
\text { a. paham } \\
\text { b. paham sebagian } \\
\text { c. tidak paham }\end{array}$ & $\begin{array}{c}41 \\
56,9 \\
2,1\end{array}$ & $\begin{array}{c}57,7 \\
41,2 \\
1,1\end{array}$ \\
\hline 2 & $\begin{array}{l}\text { Apakah kamu memanfaatkan kesempatan bertanya? } \\
\text { a. sering } \\
\text { b. kadang-kadang } \\
\text { c. tidak pernah }\end{array}$ & $\begin{array}{c}4,3 \\
52,7 \\
42,1\end{array}$ & $\begin{array}{l}14,4 \\
56,7 \\
28,9\end{array}$ \\
\hline 3 & $\begin{array}{l}\text { Mengapa kamu tidak memanfaatkan kesempatan } \\
\text { bertanya ? } \\
\text { a. takut } \\
\text { b. malu } \\
\text { c. tidak terampil }\end{array}$ & $\begin{array}{l}30,2 \\
25,6 \\
44,2\end{array}$ & $\begin{array}{l}26,6 \\
26,5 \\
46,9\end{array}$ \\
\hline 4 & $\begin{array}{l}\text { Bagaimana penampilan guru di dalam kelas? } \\
\text { a. menakutkan } \\
\text { b. simpatik } \\
\text { c. biasa-biasa saja }\end{array}$ & $\begin{array}{c}1,4 \\
40 \\
58,6\end{array}$ & $\begin{array}{c}2,1 \\
45,1 \\
52,8\end{array}$ \\
\hline 5 & $\begin{array}{l}\text { Bagaimana penampilan guru diluar kelas? } \\
\text { a. menakutkan } \\
\text { b. simpatik } \\
\text { c. biasa-biasa saja }\end{array}$ & $\begin{array}{c}2,1 \\
23,5 \\
74,4\end{array}$ & $\begin{array}{c}2,1 \\
30,6 \\
67,3\end{array}$ \\
\hline 6 & $\begin{array}{l}\text { Bagaimana sikap siswa lain jika ada siswa yang } \\
\text { bertanya? } \\
\text { a. mendengarkan } \\
\text { b. menjawab langsung } \\
\text { c. masa bodoh }\end{array}$ & $\begin{array}{c}85,1 \\
8,0 \\
6,9\end{array}$ & $\begin{array}{c}90,9 \\
3,0 \\
6,1\end{array}$ \\
\hline 7 & $\begin{array}{l}\text { Bagaimana tanggapan guru terhadap pertanyaan siswa } \\
\text { ? } \\
\text { a. melecehkan } \\
\text { b. menjawab langsung } \\
\text { c. mengembalikan kepada siswa lain }\end{array}$ & $\begin{array}{c}0,2 \\
37,8 \\
62\end{array}$ & $\begin{array}{c}0,6 \\
25 \\
74,4\end{array}$ \\
\hline 8 & $\begin{array}{l}\text { Siswa yang bertanya adalah siswa yang bodoh, } \\
\text { menurutmu ? } \\
\text { a. setuju } \\
\text { b. kurang setuju }\end{array}$ & $\begin{array}{c}1,4 \\
15,5 \\
83,1\end{array}$ & $\begin{array}{c}0,5 \\
12,8 \\
86,7\end{array}$ \\
\hline 9 & $\begin{array}{l}\text { Apakah guru menggunakan alat praga dalam mengajar } \\
\text { ? } \\
\text { a. selalu } \\
\text { b. kadang-kadang } \\
\text { c. tidak pernah }\end{array}$ & $\begin{array}{c}26,1 \\
65,2 \\
8,7\end{array}$ & $\begin{array}{l}30,2 \\
58,9 \\
10,9\end{array}$ \\
\hline 10 & $\begin{array}{l}\text { Apa yang kamu lakukan jika menemui kesulitan ? } \\
\text { a. langsung bertanya } \\
\text { b. diam saja }\end{array}$ & $\begin{array}{l}16,2 \\
34,2\end{array}$ & $\begin{array}{c}36,4 \\
10\end{array}$ \\
\hline
\end{tabular}


3) Karena terkondisi untuk bertanya, maka pemahaman siswa terhadap materi juga meningkat. Hal ini ditunjukkan dengan menurunnya prosentase siswa yang kurang paham dari 44,2\% menjadi $26,9 \%$ di akhir siklus.

Dengan demikian langkah-langkah yang ditempuh peneliti dari siklus pertama sampai siklus ketiga telah meningkatkan keberanian bertanya siswa kelas IX.E dalam kegiatan belajar mengajar. Langkah-langkah tindakan tiap siklus membawa akibat yang positif pemahaman siswa terhadap materi pembelajaran.

\section{PEMBAHASAN}

\section{Analisis Terhadap Kemampuan Guru Oleh Guru Mitra}

Setiap guru dalam mengajar selama penelitian berlangsung selalu diamati oleh mitranya dengan menggunakan Lembar Observasi. Aspek yang diamati adalah sejauh mana guru mampu melakukan : 1) Pendahuluan (apersepsi, revisi, motivasi dan introduksi), 2) Pengembangan (penguasaan materi, penggunaan metode, dan menciptakan suasana siswa aktif belajar), 3) Penerapan (kesesuaian soal dengan tujuan pembelajaran dan pengamatan terhadap kegiatan siswa), 4) Penutup(rangkuman dan pemberian tugas).

Dari hasil analisis ternyata kemampuan guru secara umum meningkat dari siklus pertama sampai dengan siklus ketiga. Hanya pada siklus ketiga mengalami penurunan karena guru mitra tidak dapat melaksanakan penelitian karena harus menhgikuti kegiatan lain di sekolah. Akibatnya guna mengejar ketinggalan materi maka pada siklus ketiga guru peneliti lebih menekankan pada aspek pengembangan sedangkan pada aspek lain dikorbankan, namun secara umum tindakan kelas dapat dikatakan berhasil memperbaiki kinerja guru.

\section{Analisis Terhadap Respon Siswa, Guru}

Tindakan kelas ini tidak luput dari respon siswa dan guru. Komentar mereka sangat bervariasi antara lain sebagai berikut :1) Guru Mitra Sejarah mengatakan bahwa diskusi kelas yang sangat aktif dan hidup, 2) Guru Mitra Ekonomi mengatakan "Jika tidak siap benar terhadap materi pembelajaran bisa kedodoran karena kelas ini sangat kritis dalam bertanya". 3) Guru Mitra Sosiologi mengatakan bahwa pembelajaran hendaknya dapat dikembangkan pada kelas lainnya, 4) Siswa kelas lain mengatakan mengapa kelas kami tidak dilakukan penelitian semacam ini, mereka menginginkan agar ada perubahan di kelasnya.

\section{KESIMPULAN}

Dari penelitian ini dapat disimpulkan bahwa tindakan kelas ini telah menimbulkan perubahan kearah yang positif. Hal ini diperngaruhi oleh tindakan guru sebagai bentuk :1)Menanamkan pentingnya pemahaman materi dalam KBM yang kemudian mengkondisikan agar siswa selalu bertanya bila menemui kesulitan, 2) Merencanakan pengajaran dengan sebaik-baiknya, termasuk di dalamnya penggunaan metode yang tepat, menguasai materi dan penggunaan alat bantu lainnya, 3)Melatih siswa trampil bertanya., 4) Senantiasa memberi motivasi agar siswa tidak canggung dalam mengajukan pertanyaan, antara lain dengan memberi pujian, tambahan nilai dan mengadakan pendekatan secara individual.

\section{SARAN}

Berdasarkan hasil penelitian tindakan yang telah dipaparkan di atas dapat dikemukakan saran-saran sebagai berikut : 1) Karena hasil yang dicapai dalam penelitian ini cukup konkrit, maka diharapkan agar pada masa mendatang penelitian ini lebih diintensifkan pada kompetensi dasar lainnya, 2) Guru IPS diharapkan memiliki kinerja yang tinggi dan lebih mengoptimalkan pemberian motivasi pada siswa untuk mengajukan pertanyaan. 


\section{DAFTAR RUJUKAN}

Arikunto, S. 1972. Prosedur Penelitian Suatu Pendekatan Praktek. Jakarta: Bina Aksara.

Herwindo, H. 1908. Bagaimana Murid Belajar. Jakarta: Dirjen Dikdasmen, Depdikbud. Pasaribu \& Simanjuntak. 1983. Proses Belajar Mengajar. Bandung: Tarsito.

Putra, Sinata. 1993. Strategi Belajar Mengajar IPS. Jakarta: Depdikbud.

Syah, M. 1995. Psikologi Pendidikan. Bandung: Remaja Rusdakarya.

Surakhmad, W. 1984. Pengantar Interaksi Belajar Mengajar. Bandung: Tarsito.

Tytler. R. 1999. Science Toys and Tricks. Australia: University Melbourne.

Windardi. 1999. Pengenalan Model Cooperative Group Investigation. Malang: PPG IPS. 